
ПРОСТОРОВО - КААСТЕРНИЙ БІЗНЕС

УДК 338.262 .8

МЕТОДИЧНІ ЗАСАДИ ФОРМУВАННЯ І РЕАЛІЗАЦІЇ СТРАТЕГІЇ
СИСТЕМНОЇ ТРАНСФОРМАЦЇ̈ ПРОМИСЛОВИХ ПДПРИСМСТВ

DOI 10.32782/2224-6282/152-10

JEL: L20, L60

\author{
Верескун М. В., Д.е.н., \\ Колосок В. М., д.е.н.,

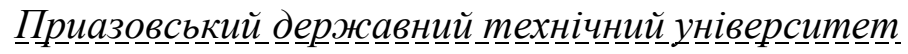

Захаров С. В. к.т.н.,

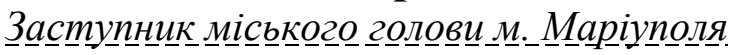

Метою роботи є розробка методичних рекомендацій щодо формування і реалізації стратегії системної трансформації вітчизняних промислових підприємств. Для досягнення мети дослідження використовувалися методи системного аналізу, сучасні концепції управляння виробництвом, аналізу та синтезу, дедукції та індукції, порівняння. Основними результати дослідження є основні підходи до організації процесу системної трансформації, до яких віднесені трансформація «по дрібницях» та комплексний підхід до трансформації. Також в роботі сформульовані вимоги щодо рівня готовності промислового підприємства до системної трансформації. Перед початком проведення системної трансформації на промисловому підприємстві мають бути: зв'язок стратегії з цілями підприємства; інвестування має проводитись лише у необхідні технології; надважливою $є$ підтримка трансформаційних процесів 3 боку топменеджменту; має бути забезпечене ефективне використання накопиченої інформації та відбуватися постійний перегляд стратегії трансформації. Важливим результатом досліджень $є$ основні заходи, що мають бути виконані в процесі системної трансформації. До переліку основних заходів віднесені: реформування корпоративної культури, кардинальна зміна бізнес моделі, оптимізація внутрішніх бізнес-процесів на основі IT-технологій та автоматизація взаємодії 3 клієнтами, постачальниками i партнерами. Крім того, в роботі виявлено основні перешкоди, які виникають перед підприємствами в процесі реалізації системної трансформації. Основним 3 них є: успадкована інфраструктура, нестача навичок, небажання цифрових змін або неготовність до них, швидкі темпи змін, відсутність узгодження з бізнес цілями, проблеми безпеки. Також в роботі запропоновані шляхи подолання названих перешкод. Отримані результати можуть бути використані для підвищення ефективності процесу формування стратегії системної трансформації промислових підприємств, а також під час організації процесу іiі проведення. Перспективним напрямком подальших досліджень $є$ адаптація і конкретизація розроблених рекомендацій з урахуванням специфіки окремих галузей та особливостей конкретних промислових підприємств.

Ключові слова: методичні засади; системна трансформація; стратегія; вітчизняні промислові підприємства; підходи до системної трансформації

() Верескун М. В., д.е.н., Колосок В. М., д.е.н., Захаров С. В., к.т.н., 2019 
UDC 338.262 .8

\section{METHODICAL FUNDAMENTALS FOR THE FORMATION AND IMPLEMENTATION OF THE SYSTEMAL TRANSFORMATION STRATEGY OF INDUSTRIAL ENTERPRISES}

DOI $10.32782 / 2224-6282 / 152-10$

JEL: L20, L60

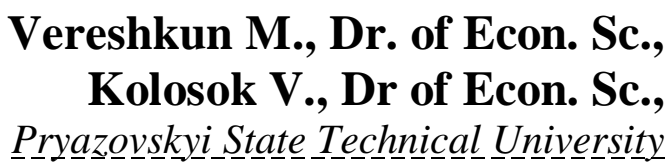

Zakharov S., Ph.D. in Technics,

Deputy_Mayor of_Maríupol

The purpose of the work is to develop methodological recommendations for the formation and implementation of the strategy of systematic transformation of domestic industrial enterprises. Methods of system analysis, modern concepts of production management, analysis and synthesis, deduction and induction, comparison were used to achieve the purpose of the study. The main results of the study are the basic approaches to organizing the process of systemic transformation, which include transformation "on the small things" and a comprehensive approach to transformation. Requirements for the level of readiness of an industrial enterprise for system transformation have been also formulated. Before undertaking a system transformation at an industrial enterprise, there should be: the connection of the strategy with the goals of the enterprise; investments should be made only in the necessary technologies; it is essential to support transformation processes by top management; the accumulated information must be effectively used and the transformation strategy constantly reviewed. An important result of the research is the main steps that must be taken in the process of systemic transformation. The main activities include: corporate culture reform, a radical change in business model, optimization of internal business processes based on IT technologies and automation of interaction with customers, suppliers and partners. In addition, the main obstacles that arise for enterprises in the implementation of system transformation have been identified. The main ones are: legacy infrastructure, lack of skills, unwillingness or unpreparedness for digital change, rapid pace of change, lack of alignment with business goals, security issues. The paper also proposes ways to overcome these obstacles. The results obtained can be used to increase the efficiency of the process of forming a systematic transformation strategy of industrial enterprises, as well as to organize the process of its implementation. A promising direction for further research is the adaptation and concretization of the developed recommendations, taking into account the specifics of individual industries and the characteristics of specific industrial enterprises.

Keywords: methodical foundations; system transformation; strategy; domestic industrial enterprises; approaches to system transformation

Актуальність. Нагальною необхідністю для вітчизняних промислових підприємств $€$ усвідомлення необхідності постійного удосконалення бізнесу, підвищення рівня його ефективності. Пошук можливостей, прийомів і заходів, систем і методологій кардинального 
підвищення ефективності має стати однією з постійних функцій і бути включеною в бізнес-модель діяльності промислових підприємств.

Сучасні тенденції розвитку світової економіки визначено Четвертою індустріальною революцією, яка все більше набирає обертів. Роботизація виробництв суб'єктів господарської діяльності - це реальність сьогодення в розвиненому світі, який стає все більш щільним та інтегрованим, завдяки використанню досягнень науково-технічного прогресу. Ці процеси $\epsilon$ поштовхом для системної трансформації суб'єктів господарювання, яка стає не просто умовою їхнього подальшого розвитку, а нагальною необхідністю, яка забезпечує можливість на рівних приймати участь у конкурентній боротьбі на глобальних ринках товарів і послуг. Така ситуація змінює підходи не тільки до стратегічного управління загалом, а й до розроблення та формування трансформаційних стратегій зокрема.

Слід також зауважити, що трансформаційні процеси в середовищі розвинених країн із коректними ринковими умовами $\epsilon$ запорукою еволюційного розвитку соціально-економічних систем і сприймаються без особливих заперечень. Проте, переважна більшість сучасних промислових підприємств в економіці України зобов'язані своєю появою революційним процесам стрімкого переходу від соціалістичних соціально-економічних відносин до капіталістичних. Вже неодноразово відзначалося, що інструментарій, який був використаний для реалізації цих системних перетворень, а саме, приватизація, реформування, реорганізація, реструктуризація, санація, модернізація та інші - не дали бажаних результатів. Головною причиною цього вважається наявність великої кількості системних проблем вітчизняних підприємств, а також відсутність адекватної методології їх еволюційного подолання. Дуже суттєвий негативний вплив на ситуацію спричинила геополітична криза та військові дії на сході України, які призвели до розриву великої кількості економічних зв'язків, втрати традиційних ринків збуту та переорієнтації економіки на європейські ринки, для яких переважна більшість промислових підприємств України не може запропонувати конкурентоспроможних товарів та послуг.

Отже, дослідження в галузі розробки методичних рекомендацій щодо організації процесу системної трансформації вітчизняних промислових підприємств стають особливо актуальними саме сьогодні, коли трансформаційні процеси, які мають на меті перехід до Четвертої індустріальної революції, значно пришвидшуються під тиском геополітичних проблем і військових конфліктів. 
Аналіз останніх наукових досліджень та публікацій. Питанню стратегічного управління підприємствами, зокрема розробленню та реалізації їх трансформаційних стратегій, присвячено праці вітчизняних і зарубіжних учених, зокрема: В. С. Пономаренка, 3. Є. Шершньової, С. В. Оборської, Л. Д. Заблодської, О. І. Пушкаря, В. Д. Нємцова, Л. С. Довгань, П. М. Кобзєва, Д. Аакера, М. І. Круглова, І. Ансоффа, А. Томпсона, Дж. Стрікленда, Г. Мінцберга, Дж. Б. Куїнна, С. Гошала та ін. Названі вчені зробили вагомий внесок у розвиток теорії та практики стратегічного управління підприємствами, зокрема в питання розроблення, формування та реалізації трансформаційних стратегій.

Проте, переважна більшість авторів ставить знак рівняння між західною фірмою та вітчизняним промисловим підприємством, не беручи до уваги значні системні відмінності як у внутрішній структурі, так і у зовнішніх процесах, що чинять безпосередній вплив на їх формування i розвиток. Наявність цих відмінностей призводить до того, що застосування у вітчизняній практиці ряду апробованих у розвинутих економічних системах положень не призводить до бажаних результатів, що актуалізує розгляд питань, пов'язаних 3 формуванням та впровадженням стратегій системної трансформації саме вітчизняних промислових підприємств.

Метою роботи $\epsilon$ розробка методичних рекомендацій щодо формування і реалізації стратегії системної трансформації вітчизняних промислових підприємств.

Виклад основних результатів дослідження. Само поняття «трансформація» в його економічному розумінні було достатньо повно досліджено Є.А.Івченко. Відповідно до результатів зазначеного дослідження «трансформація позначає якісні перетворення або становлення економічної системи різного масштабу, що дозволяє перехід на новий рівень функціонування і розвитку системи, який здійснюється послідовно та безперервно на всіх рівнях економічної системи» [1] .

Проте, наведене визначення залишає відкритим питання щодо напрямів такого перетворення стосовно промислових підприємств, а також щодо підходів до управління цими процесами. Вважаємо, що в умовах глобалізації і політичного курсу України на інтеграцію у європейські економічні структури основним напрямом трансформації має стати доведення стану всіх систем промислового підприємства до такого рівня, який буде відповідати сучасним тенденціям розвитку світової економіки і дозволить йому витримувати глобальну конкуренцію на світовому ринку. 
Визначальною рисою сьогоднішнього етапу розвитку світової економіки є те, що умови взаємодії штучно створених людиною суб' єктів господарювання та сама їх внутрішня структура визначаються вже не стільки тим, що все знаходиться у постійному русі і постійно змінюється, а тим, що кількість накопичених людиною знань і створених технологій сформувала передмови для початку 4-ї індустріальної революції, яка не просто змінює «правила та умови гри», а призводить до зміни самого типу цивілізації [2].

У своїй роботі К. Шваб визначив основні рушійні фактори 4-ї індустріальної революції, систематизувавши їх за трьома ключовими блоками:

•фізичний блок: безпілотні транспортні засоби, 3-D друк, передова робототехніка, нові матеріали;

•цифровий блок: Інтернет речей , який має під собою взаємодію між речами (продуктами, послугами, містами та ін.) та людьми, яке забезпечується взаємопов'язаними технологіями та різноманітними платформами;

•біологічний блок: інновації в біологічній сфері, зокрема в генетиці, що дає можливість створювати генетично модифіковані рослини та тварин, а також створення клітин дорослих організмів, включно людей [3].

На нашу думку, головною особливістю цих факторів $є$ те, що всі вони стають можливими завдяки активному використанню IT-технологій. При чому це стосується кожного з блоків. Іншими словами, одною з основих передумов початку 4-ї індустріальної революції стає відповідний рівень розвитку IT-технологій і всієї супутньої інфраструктури.

Навіть експрес аналіз стану відповідності вітчизняних промислових підприємств новим вимогам свідчить про їх неготовність, за рідкими винятками, до конкурентної боротьби за ринки товарів і ресурсів. Так, менш ніж 1\% українських товарів та послуг $є$ конкурентоспроможним у світовому ринковому середовищі, а Україна посіла 83 місце у рейтингу глобальної конкурентоспроможності у 2018 році [4].

Тому для вітчизняних підприємств мова має йти не про розвиток, а про системну трансформацію, методологічною основою якої має стати відповідна стратегія системної трансформації промислових підприємств.

Як вже підкреслювалось, в основі стратегії системної трансформації має бути якомога швидша IT-тарсформація, спрямована на використання високих технологій для кардинального підвищення продуктивності вітчизняних промислових підприємств. Досягнення у цій галузі докорінно змінюють процеси управління бізнесом, дають можливість 
швидше формувати найбільш привабливі конкурентні пропозиції, змінюють підходи до роботи з персоналом та до обслуговування клієнтів. Результати останніх досліджень свідчать, що компанії, які пройшли ITтрансформацію, є на 26\% прибутковішими, аніж їх основні конкуренти в галузі, а їх ринкова вартість є на $12 \%$ віщою [5].

Наведені данні свідчать, що системна трансформація стає необхідною умовою подальшого розвитку промислових підприємств. Вже сьогодні існування промислових підприємств без застосування цифрових технологій $є$ неможливим. I в подальшому тенденція буде тільки посилюватись, призводячи до повної цифровізації бізнес-ресурсів. Неодноразово доведено, що використання цифрових технологій на промислових підприємствах призводить не тільки до суттєвого підвищення ефективності використання всіх видів ресурсів, а й до збільшення продуктивності самих підприємств. Важливо розуміти, що системна трансформація - це не тільки автоматизація всіх технологічних процесів на основі використання сучасної техніки та відповідного програмного забезпечення, а й збільшення швидкості і якості процесу прийняття i реалізації рішень в системі управління на всіх без виключення рівнях.

Слід зауважити, що системна трансформація є досить складним процесом, який потребує грунтовної підготовки. Тому стратегією такої трансформації повинні бути передбачені ряд підготовчих заходів, реалізація яких дозволить провести цю процедуру 3 мінімальними ускладненнями.

Проведені дослідження дозволили виявити п'ять основних вимог, реалізація яких дозволить промисловому підприємству якнайкраще підготуватись до цієї складної процедури.

1. Забезпечення щільного зв'язку стратегії системної трансформації із основними цілями підприємства.

Дослідження розуміння необхідності трансформації довели дуже високий рівень розуміння цієї тенденції. Так, 96\% з числа опитаних керівників промислових підприємств вважає, що системна трансформація дуже важлива, або критична для їх розвитку. Проте, завжди є загроза проведення трансформації за принципами «щоб було» або «як у всіх». Зрозуміло, що цей шлях $є$ хибним, а ефективність використання коштів, витрачених на таку трансформацію, вкрай низькою. Тому, насамперед, промисловим підприємствам необхідно визначити, де саме зміни є найнеобхіднішими.

Для цього необхідно визначити основні цілі бізнесу, та чітко визначити, за допомогою яких показників (коротко-, середньо- та 
довгострокових) буде оцінюватись ступінь їх досягнення. Далі необхідно зрозуміти, які саме технології можуть в цьому допомогти. Наприклад, якщо основна мета підприємства - швидкий вихід на новий ринок, то заплановану раніше інвестицію у штучний інтелект доцільно відкласти, визначивши в якості першочергового завдання системної трансформації налагодження надійної хмарної інфраструктури, яка дозволить підтримувати основні бізнес процесі із різних місць.

2. Виважені інвестиції тільки у необхідні технології.

Системна трансформація для різних підприємств може досить суттєво відрізнятись. При цьому крупні інвестиції зовсім не є запорукою успіху. Результати досліджень вітчизняних i закордонних вчених дозволили визначити три основні IT технології, які спричиняють найбільший вплив на виробничі процеси. По-перше, це інтернет речей, який здатний забезпечити зв'язок між окремими операціями; по-друге, це хмарні технології, які мають фактично необмежений потенціал масштабування та big data analytics, яка дозволяє перетворити великі масиви структурованих даних на ефективну систему підтримки прийняття управлінських рішень.

Проте, універсального рішення немає. Результати проведених досліджень свідчать, що 19\% виробників планують інвестувати в рішення для управління складом, 18\% - у хмарні технологіï, big data та управління роботою з клієнтами, а 17\% - у впровадження мобільних технологій.

Велика кількість варіантів обумовлює необхідність переконатись, що підприємство інвестує кошти саме в ті технології, які їм необхідні. Дехто отримає миттєвий зиск від впровадження хмарних технологій, проте підприємство, яке не має розгалуженої мережі філій і розташовано в одному місці, в першу чергу розгляне інше рішення. Інвестиції такого підприємства мають шанс окупитися швидше, якщо данні будуть зберігатися на сервері підприємства, а кошти будуть інвестовані у придбання ERP системи, яка дозволить використовувати big data для співставлення рівня запасів на складі та отриманих замовлень, а також проводити моніторинг ланцюгів постачань в режимі реального часу. Проте, за умов вірного вибору впроваджена ERP-система буде настільки гнучкою, що дозволить перевести данні у хмари, якщо це буде доцільним.

3. Підтримка топ-менеджменту.

Успішна стратегія системної трансформації змінює бізнес. Вона впливає на всі сфери управління: на те як люди виконують завдання, як співпрацюють, на самі робочі місця. Для великої кількості підприємств суттєвою проблемою стає знаходження порозуміння між IT керівництвом i топ-менеджментом компанії. Проте, дуже важливо, щоб вище 
керівництво компанії особисто приймало участь у змінах. Це дозволить уникнути спротиву і непорозуміння з їх боку. Особливо це важливо в тому випадку, якщо IT технології впроваджуються для виконання завдань, які раніше виконувались людьми, адже в цьому випадку інвестиції можуть не окупитися досить швидко.

4. Ефективне використання накопиченої інформації.

Сьогодні IT системи збирають неймовірну кількість даних про всі аспекти діяльності промислового підприємства. Проте, наявність величезних масивів даних $\epsilon$ недостатнім результатом системної трансформації. Надважливим є вміння ефективно їх використовувати, корегуючи траєкторію змін або знаходячи, на основі їх аналізу, нові джерела прибутку. Наприклад, на останніх IT рішень в галузі аналізу даних стало можливим отримувати таку інформацію, як тенденції $\mathrm{i}$ прогнози поведінки покупців, або обсяги продажів конкретного продукту.

5. Постійний перегляд стратегії трансформації.

Системну трансформацію слід сприймати, як подорож без кінця. Адже процес появи нових технологій триває постійно і темпи його тільки зростають. Так, від порівняно простих роботів, які виконують виробничі операції швидше і точніше, ніж люди, ми вже сьогодні маємо змогу перейти до складних автоматів, які здатні вирішувати проблеми 3 основним обладнанням без його зупинки.

Як зазначав Чарльз Дарвін «виживає не найсильніший i найрозумніший, а той, хто найкраще пристосується до змін». Цей вислів вченого справедливий не тільки для тваринного світу, а є повністю актуальним для сучасної економічної системи в межах якої існують вітчизняні промислові підприємства. Тому дуже важливо постійно відслідковувати процеси трансформації та адаптувати стратегію системної трансформації до нових викликів і можливостей, проводити аналіз змін - чи відповідають вони вашим очікуванням, або очікуванням ваших клієнтів? Як те що відбувається на підприємстві співвідноситься із філософією і цілями вашого бізнесу? Якщо змінюються цілі, то мають змінитися і технології. Наприклад, інноваційні рішення для планування i управління виробничими ресурсами (ERP) разом з розробками в межах концепції Індустрії 4.0 вже дали змогу автоматизувати виробничі лінії, значно прискорити ланцюги постачань i надати інформацію, яка необхідна виробникам для швидкого реагування на зміну рівня попиту на ринку.

Наведені данні однозначно свідчать, що для вітчизняних промислових підприємств проведення системної трансформації це не 
питання більшої, або меншої ефективності, більших або менших прибутків. Це питання продовження існування, як такого. Якщо знехтувати цими процесами, або провести їх неефективно, підприємство буде приречене, адже воно не зможе знизити собівартість своїх товарів та послуг до рівня тих цін, які пропонують конкуренти, які вже встигли «трансформуватися».

Проведені дослідження свідчать про існування великої кількості варіантів проведення системної трансформації, проте всі вони передбачають певний набір обов'язкових заходів, без реалізації яких трансформація не принесе бажаного результату. Основними з них є:

•реформування корпоративної культури підприємства;

•кардинальну зміну бізнес-моделі;

- оптимізація внутрішніх бізнес-процесів підприємства за допомогою впровадження сучасних технологій;

-автоматизація взаємодії з клієнтами, постачальниками i партнерами.

Складність полягає в тому, що послідовна реалізація цих заходів неможлива. Всі описані процеси мають відбуватися паралельно. Проте, незважаючи на складність і досить суттєві ризики, світова індустрія чудово розуміє безальтернативність названого шляху. Про це свідчать данні дослідження компанії IDC, які говорять про те, що за останні 4 роки зростання витрат на системну трансформацію спостерігалося щорічно на рівні 15-20\% і наприкінці 2020 р. їх рівень абсолютному виразі має перевищити \$ 2 трлн.

Незважаючи на певну єдність думок щодо основних заходів, що $\epsilon$ запорукою ефективності системної трансформації промислових підприємств $є$ суттєві розбіжності щодо конкретних способів іiі здійснення. Так, ряд дослідників і практиків впевнені, що трансформацію слід проводити «по дрібницях», інші вважають, що треба використовувати комплексний підхід. Розглянемо обидва варіанти.

1) Системна трансформація «по дрібницях».

Такий метод реалізації стратегії системної трансформації передбачає довільну, точкову трансформацію бізнес-процесів 3 використанням сучасних технологій. Основою концепції $є$ гнучкий підхід до трансформації виробничих операцій. Промисловим підприємствам рекомендується за необхідності виконати наступні дії:

-впровадити системи збору та аналітики даних.

Практика доводить, що аналітика великих даних є дієвим способом отримання масштабних результатів в максимально стислі терміни. Але, 
вибір даного підходу передбачає впровадження сучасних технологій для зберігання і обробки даних, а також залучення таких експертів в області інформаційних технологій, які здатні точно визначити, де і яким чином застосувати отримані дані, щоб отримати максимальну вигоду для бізнесу;

-автоматизувати взаємодії з контрагентами;

-використовувати хмарні сервіси для забезпечення повсюдного доступу співробітників до робочих файлів і додатків 3 мобільних пристроїв (особливо актуально для фахівців, що працюють віддалено і на виїзді);

•розробити мобільний додаток, щоб забезпечити клієнтам більш швидкий, зручний і якісний сервіс;

-трансформувати бізнес-процеси у відповідності до нових вимог.

Реалізація запропонованих дій дозволить суттєво знизити ризики, пов'язані із реалізацією трансформаційних процесів.

2) Комплексний підхід до системної трансформації.

Результати проведених досліджень дозволили розробити покрокове керівництво для системної трансформації промислових підприємств. Вигідно 3 ним, важливою умовою для створення «розумного підприємства» $\epsilon$ забезпечення щільного зв'язку i координації між обчислювальними потужностями і фізичними ресурсами. Для того щоб стати динамічним, адаптивним, сучасним промисловим підприємством, компанія має подолати наступні шість рівнів:

1. Комп'ютеризація - впровадження автоматизованих систем управління всіма ключовими процесами виробництва, а також закупівля обладнання, яке піддається цифровому управлінню.

2. Мережева взаємодія - об'єднання різних технологічних рішень в єдину середу Internet of things (Інтернет речей). Як правило, по протоколу IP між собою інтегруються системи автоматизованого проектування i виробництва (CAD/CAM), управління технологічними процесами (MES), а також нове або модернізоване старе обладнання. Також повинна бути передбачена можливість дистанційного обслуговування цього середовища.

3. Оглядовість - відображення актуальної робочої картини підприємства в цифровій/віртуальній формі. Може бути досягнена різна ступінь оглядовості за рахунок встановлення датчиків на виробниче обладнання та впровадження систем PLM, ERP i MES. Разом 3 автоматизацією обліку така система дозволяє приймати більш оперативні та ефективні управлінські рішення. 
4. Прозорість - інтеграція середовища цифрового відображення підприємства з системами аналітики (зокрема, інструментами обробки великих даних).

5. Прогнозування - впровадження адаптованих під вимоги конкретного виробництва технологій предикативної аналітики (технологій прогнозування).

6. Адаптивність - автоматизація функцій, що відповідають за гнучкість, адаптацію бізнесу до динамічних умов навколишнього i внутрішнього середовища.

Незважаючи на обраний підприємством варіант системної трансформації, ключовим фактором успіху буде людський фактор. Нi оптимізація бізнес-процесів, ні їх суцільна автоматизація, ні технічне та програмне забезпечення не мають такого значення, як поведінка співробітників. Для ефективного проведення системної трансформації необхідно сформувати на підприємстві відповідну атмосферу. Вам будуть необхідні так звані «агенти змін», які будуть підтримувати ідею трансформації незважаючи на проблеми і незручності, які неодмінно будуть виникати у процесі іiі впровадження. В ході досліджень, виявлено, що ключовими характеристиками таких співробітників $є$ :

-відкритість і готовність к змінам - постійному впровадженню інновацій у свої трудові операції, постійному професійному розвитку;

-здатність до відкритої соціальної взаємодії - демократичному стилю керівництва, можливості відкрито висловлювати свою точку зору, активній участі у розвитку підприємства.

У 2017 р. Технічний університет Мюнхена разом із компаніями «SAP» та «Accenture» випустив дослідження під назвою «Навички цифрової трансформації», яке свідчить, що 90\% вищих керівників промислових компаній (загалом, було опитано 116 керівників із 18 країн) розглядають системну трансформацію, як основу своїх бізнес стратегій [6].

Проте, незважаючи на безальтернативність системної ITтрансформації, існує велика кількість загроз, здатних не тільки знизити ефективність проведених перетворень, а й взагалі зруйнувати бізнес [7]. Проведена систематизація і структуризація можливих загроз і ризиків, дозволила виділити основні перешкоди на шляху успішної системної трансформації, а також запропонувати стратегічні рішення для їх подолання.

1. Успадкована інфраструктура.

Як правило промислові підприємства не будуються «з нуля», вони мають певну історію і накопичений досвід в організації і способах 
забезпечення основних і допоміжних бізнес процесів. Проте, як правило існуюча інфраструктура характеризується нагромадженням ручних процесів і обмеженими можливостями щодо аналітики.

Більшість вчених i практиків вважають, що ключовими компонентами інфраструктури сучасного промислового підприємства має стати використання хмарних технологій та передові рішення в сфері аналітики. Найбільш ефективними технологіями вважаються роботизація бізнес-процесів (RPA), машинне навчання та штучний інтелект, що призначені для обробки даних і підтримки процесів прийняття рішень. На сьогодні успішною буде вважатися та інфраструктура, яка дозволить створювати і масштабувати софт протягом наступних 10 років.

2. Нестача навичок.

Проведені дослідження довели, що зміна інфраструктури найчастіше призводить до зміни технологічної команди. При цьому, за даними досліджень, тільки 15\% керівників мають знання і навички, необхідні для реалізації системної трансформації. Серед ключових виконавців відсоток ненабагато кращий - більше половини з них зовсім не готові до системної IT-трансформації. Навіть високо кваліфіковані керівники відчувають гостру нестачу ключових виконавців, обізнаних у таких галузях, як штучний інтелект, блокчейн, бізнес-аналітика, кібербезпека, робототехніка, big data analytics, хмарні технології. Проблема ускладнюється ще й тим, що окрім названого, співробітники повинні мати певну ділову хватку та навички співробітництва. Тому важливою умовою успішної системної трансформації $\epsilon$ організація системи постійного навчання та найму нових співробітників.

3. Небажання цифрових змін або неготовність до них.

Визначено, що визначним якісним параметром ефективності системної трансформації є ставлення до неї команд та бізнес-підрозділів. I мова йде не лише про готовність освоювати нові навички. За результатами проведених досліджень більшість співробітників (42\%) занепокоєна різкими змінами. I тут вирішальне значення буде відігравати рішучість керівництва і його вміння продемонструвати значущість трансформації на всіх рівнях управління. Тому дуже важливою $\epsilon$ системна організація ефективної роз'яснювальної роботи, яка була б спрямована на моделювання підсумків трансформації у позитивному руслі, підвищення рівня вмотивованості персоналу компанії та зміну способу мислення. Також необхідно організувати відкриті дискусії, семінари та тренінги, на яких співробітники мали б змогу обговорити хвилюючі х питання щодо системної трансформації. Одним з основних 
завдань керівництва компанії на цьому етапі $\epsilon$ вислухати кожного співробітника, а потім захопити його ідеєю трансформації.

4. Швидкі темпи змін.

Результати проведених досліджень свідчать, що послідовне подолання перешкод в процесі системної трансформації здатне перетворити компанію у структуру, яка готова постійно змінюватись завдяки тому, що подолані перешкоди надають їй гнучкості та вносять суттєві зміни у саму культуру компанії.

Проте дуже важливими є не тільки готовність змінюватися, а й темпи змін. Занадто швидкий темп неодмінно призведе до зайвого перевантаження і невпинного «пристосуванства», занадто повільний призведе до втрати інтересу до системної трансформації [8]. Результати проведених досліджень свідчать, що часто існує певний розрив між швидкістю впровадження інновацій в IT індустрії і IT службах промислових підприємств. I в цій ситуації дуже важливо концентруватись на основних бізнес-процесах $\mathrm{i}$ не допустити впровадження інновацій «заради самих інновацій». Однією із можливих стратегій може бути стратегія «N-minus-one», яка передбачає відмову від новітньої функції, що впроваджується, скажімо, IT провайдером, на користь більш старої (на крок назад), але і більш стабільною функції.

5. Відсутність узгодження з бізнес-цілями.

Суттєвою перешкодою для досягнення цілей сисної трансформації може стати відсутність зв'язку між перебудовою IT-інфраструктури і досягненням власне цілей бізнесу [9]. Досить часто трапляються ситуації, коли в керівників IT-відділів дуже амбітні і переконливі плани системної трансформації, , які, нажаль, не $\epsilon$ узгодженими із основними стратегічними цілями компаній і результатом реалізації яких стають суттєві збитки. Тому план трансформації має враховувати інтереси всіх зацікавлених сторін аби уникнути скорочення фінансування і згортання програм трансформації.

6. Проблеми безпеки.

Дуже часто камінням спотикання на шляху до швидкої системної трансформації є проблема забезпечення безпеки. Виявлено, що це друга за питомою вагою перешкода після неготовності або небажання приймати системні зміни, проте для багатьох компаній ця перешкода є найвагомішою. В цілому, промислові компанії розуміють, що системна трансформація пов'язана з величезною кількістю загроз. І цих загроз тим більше, чим швидше компанія намагається провести трансформацію. 
Для подолання цієї перешкоди можна порадити використовувати двоетапну систему зниження ризиків, пов'язаних з рівнем безпеки. На першому етапі розробляється система внутрішньої сертифікації.

Таблиця 1 - Методичні рекомендації щзодо реалізації стратегії системної трансформачії промислових підприємств

\begin{tabular}{|c|c|c|c|c|c|c|}
\hline \multicolumn{7}{|c|}{ Підходи до системної трансформації } \\
\hline \multicolumn{5}{|c|}{ Трансформація «по дрібницях»: основні дї } & \multicolumn{2}{|c|}{$\begin{array}{l}\text { Комплексний підхід: } \\
\text { основні рівні }\end{array}$} \\
\hline \multicolumn{5}{|c|}{ Впровадження системи аналітики та збору даних; } & \multicolumn{2}{|c|}{ Комп’ютеризація; } \\
\hline \multicolumn{5}{|c|}{ Автоматизація взаємодії з контрагентами; } & \multicolumn{2}{|c|}{ Мережева взаємодія; } \\
\hline \multicolumn{5}{|c|}{ Використання хмарних сервісів; } & \multicolumn{2}{|c|}{ Оглядовість; } \\
\hline \multicolumn{5}{|c|}{$\begin{array}{l}\text { Розробка і використання мобільного додатку для } \\
\text { Ітів; }\end{array}$} & \multicolumn{2}{|c|}{ Прозорість; } \\
\hline \multicolumn{5}{|c|}{$\begin{array}{l}\text { Трансформація бізнес-процесів у відповідності до } \\
\text { нових вимог }\end{array}$} & \multicolumn{2}{|c|}{ Прогнозування } \\
\hline & & & & & \multicolumn{2}{|c|}{ Адаптивність } \\
\hline \multicolumn{7}{|c|}{ Основні вимоги щодо рівня готовності до системної трансформації } \\
\hline \begin{tabular}{l}
\multicolumn{1}{c|}{ Зв'яз } \\
ок стратегії 3 \\
цілями \\
підприємств \\
a \\
\end{tabular} & \multicolumn{2}{|c|}{ 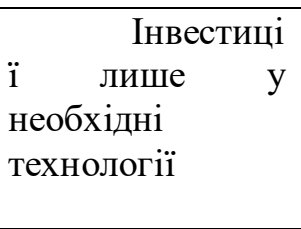 } & $\begin{array}{r}\text { Підтримка } \\
\text { топ-менеджменту }\end{array}$ & \multicolumn{2}{|c|}{$\begin{array}{l}\text { Ефективне } \\
\text { використання } \\
\text { накопиченої } \\
\text { інформації }\end{array}$} & $\begin{array}{ll} & \text { Постійн } \\
\text { ий } & \text { перегляд } \\
\text { стратегії } & \\
\text { трансформації }\end{array}$ \\
\hline \multicolumn{7}{|c|}{ Обов'язкові заходи в межах системної трансформа } \\
\hline \multicolumn{2}{|c|}{$\begin{array}{lr} & \text { Реформуван } \\
\text { ня } & \text { корпоративної } \\
\text { культури }\end{array}$} & \multicolumn{3}{|c|}{\begin{tabular}{l}
\multicolumn{2}{r}{ Кардиналь } \\
на зміна бізнес \\
моделі
\end{tabular}} & \multicolumn{2}{|c|}{$\begin{array}{l}\text { Автоматизація } \\
\text { одії } 3 \text { клієнтами, } \\
\text { чальниками } \\
\text { rерами. }\end{array}$} \\
\hline \multicolumn{7}{|c|}{$\begin{array}{c}\text { Основні перешкоди на шляху вдалої системної трансформації та шляхи їх } \\
\text { подолання }\end{array}$} \\
\hline \multicolumn{4}{|c|}{ Перешкоди } & \multicolumn{3}{|c|}{ Шляхи подолання } \\
\hline \multicolumn{4}{|c|}{ Успадкована інфраструктура. } & \multicolumn{3}{|c|}{$\begin{array}{l}\text { Використання } \quad \text { хмарних } \\
\text { технологій та бізнес-аналітики }\end{array}$} \\
\hline \multicolumn{4}{|c|}{ 2. Нестача навичок. } & \multicolumn{3}{|c|}{\begin{tabular}{l}
\multicolumn{1}{c}{ Організація } \\
постійного навчання та найму нових \\
працівників
\end{tabular}} \\
\hline \multicolumn{4}{|c|}{ Небажання цифрових змін або неготовність до } & \multicolumn{3}{|c|}{$\begin{array}{ccc}\text { Вислухати } & \text { кожного } \\
\text { переконати в необхідності змін }\end{array}$} \\
\hline \multicolumn{4}{|c|}{ 4. Швидкі темпи змін. } & minus-o & $\begin{array}{l}\text { Використан } \\
\text { ne» }\end{array}$ & чя стратегії «N- \\
\hline Відсутн & гість $y^{3}$ & годження 3 & бізнес цілями. & $\begin{array}{l}\text { погодж } \\
\text { підгото } \\
\text { зацікав. }\end{array}$ & $\begin{array}{l}\text { Звернути } \\
\text { ення, врахс } \\
\text { вки страте } \\
\text { лених сторі⿱ }\end{array}$ & $\begin{array}{l}\text { увагу } \\
\text { зувати в процесі } \\
\text { iii інтереси всіх }\end{array}$ \\
\hline Пробле & ми без & пеки & & $\begin{array}{l}\text { системи } \\
\text { пов'яза }\end{array}$ & $\begin{array}{l}\text { Використан } \\
\text { I } \quad \text { зниж } \\
\text { них з безпег }\end{array}$ & $\begin{array}{lr}\text { чя } & \text { двоетапної } \\
\text { ння } & \text { ризиків, } \\
\text { ою. } & \end{array}$ \\
\hline
\end{tabular}


На другому етапі всі вхідні технології, що плануються до інтеграції в систему компанії, проходять аудит на предмет відповідності системним вимогам і можливостям. Такі заходи дозволять досягти контрольованого рівня ризику.

Узагальнені результати проведених досліджень можна представити у вигляді таблиці 1.

Висновки. Основним результатом проведених досліджень $\epsilon$ сформульовані методичні рекомендації щодо процесів формування i реалізації стратегії системної трансформації вітчизняних промислових підприємств.

1. Сьогоднішній етап розвитку світової економіки характеризується переходом до 4-ї індустріальної революції, основними рушійними силами якої $є$ фізичний блок (3D друк, робототехніка, нові матеріали), цифровий блок (Інтернет речей) та біологічний блок (інновації в генетиці). Очевидним $є$ факт, що розвиток кожного з блоків неможливий без використання на всіх етапах сучасних IT-технлогій.

Для вітчизняних промислових підприємств проведення системної трансформації це не питання більшої, або меншої ефективності, більших або менших прибутків. Це питання продовження існування, як такого. Якщо знехтувати цими процесами, або провести їх неефективно, підприємство буде приречене, адже воно не зможе знизити собівартість своїх товарів та послуг до рівня тих цін, які пропонують конкуренти, які вже встигли «трансформуватися». Тобто, системна трансформація, орієнтована на широке використання IT-технологій, $\epsilon$ безальтернативним шляхом розвитку сучасних промислових підприємств.

2. Узагальнення результатів досліджень вітчизняних i закордонних вчених дозволило дійти висновку про існування двох підходів до системної трансформації. Перший підхід передбачає трансформацію «по дрібницях», другим є так званий комплексний підхід до трансформації. Перший підхід передбачає: впровадження системи аналітики та збору даних, автоматизація взаємодії з контрагентами, використання хмарних сервісів, розробка і використання мобільного додатку для клієнтів, трансформація бізнес-процесів у відповідності до нових вимог. Для реалізації комплексного підходу підприємство має пройти наступні рівні: комп'ютеризація, мережева взаємодія, оглядовість, прозорість, прогнозування, адаптивність.

3. Доведено, що системна трансформація $\epsilon$ складним, комплексним процесом, який потребує грунтовної підготовки. Тому стратегією системної трансформації повинні бути передбачені ряд 
підготовчих заходів, реалізація яких дозволить провести цю процедуру 3 мінімальними ускладненнями.

Проведені дослідження дозволили виявити п'ять основних вимог, реалізація яких дозволить промисловому підприємству якнайкраще підготуватись до цієї складної процедури: забезпечення щільного зв’язку стратегії системної трансформації із основними цілями підприємства, виважені інвестиції тільки у необхідні технології, підтримка топменеджменту, ефективне використання накопиченої інформації, постійний перегляд стратегії трансформації.

4. Результати досліджень свідчать про існування великої кількості варіантів проведення системної трансформації, проте всі вони передбачають певний набір обов'язкових заходів, без реалізації яких трансформація не принесе бажаного результату. Основними 3 них є: реформування корпоративної культури підприємства; кардинальна зміна бізнес-моделі; оптимізація внутрішніх бізнес-процесів підприємства на базі сучасних ІТ-технологій; автоматизація взаємодії 3 клієнтами, постачальниками і партнерами.

5. В процесі дослідження були виявлені основні перешкоди на шляху реалізації системної трансформації та запропоновані заходи, спрямовані на їх подолання.

Перспективним напрямком подальших досліджень є адаптація i конкретизація розроблених рекомендацій 3 урахуванням специфіки окремих галузей та особливостей конкретних промислових підприємств.

\section{СПИСОК ВИКОРИСТАНИХ ДЖЕРЕЛ:}

1. Івченко Є.А. Трансформація, як поняття та підходи до його розуміння у економічному контексті. Ефективна економіка. 2015. №12. URL: http://www.economy.nayka.com.ua/?op=1\&z=5827.

2. Черниговская T. В. Научные лекции. 10. Прямая речь: веб-сайт. URL: https://www.pryamaya.ru/tatyana_chernigovskaya].

3. Шваб К. Четвертая промышленная революція. М. «Эксмо», 2016. с. 17-26.

4. Shwab K. The Global Competitiveness Report 2018. World Economic Forum. URL: http://www3.weforum.org/docs/GCR2018/05FullReport/TheGlobalCompetitivenessRepo rt2018.pdf.

5. Хиски Т. Готовимся к цифровой трансформации в пять шагов. CAD/CAM и производственные процессы: публикации. Веб-сайт. URL: https://www.dreambird.ru/articles/2018/5-steps-digital-transformation.

6. Стельиах С. Шесть барьеров на пути цифровой трансформации и стратегии по их преодолению. IT-Week №4 (940). URL: https://www.itweek.ru/digitalization/article/ detail.php?ID=201706. 
7. Пушкар О.I. Грабовський Є.M., Пономаренко Е.В. Стратегічне управління розвитком електронного бізнесу та інформаційних ресурсів підприємства (моделі, стратегії, механізми): наукове видання. М.: ХНЕУ, 2005. 478 с.

8. Шершньова 3.Є. «Розбудова системи управління бізнес - організацій в інноваційній економіці»: монографія Л.О.Лігоненко, О.І.Гарафонова, Т.В. Омельяненко та ін. К. : КНЕУ. 2017. 436 c.

9. Томпсон-мл. Артур А., Стрикленд III А. Дж. Стратегический менеджмент. Концепции и ситуации для анализа. 12-е изд., Пер. с англ. М.: Изд. дом «Вильямс», 2006. 928 c.

\section{REFERENCES:}

1. Ivchenko E.A. (2015), "Transformation as a concept and approaches to its understanding in the economic context", ["Transformacija, jak ponjattja ta pidhody do jogo rozuminnja u ekonomichnomu konteksti"], Effective Economics. No.12, available at: http://www.economy.nayka.com.ua/?op=1\&z=5827.

2. Chernigovskaya T.V. "Scientific lectures. 10", Direct speech ["Nauchnye lekcii. 10"], available at: https://www.pryamaya.ru/tatyana_chernigovskaya.

3. Schwab, K. (2016), "The Fourth Industrial Revolution", ["Chetvertaja promyshlennaja revoljucija"], M., "Exmo", pp. 17-26.

4. Shwab K. "The Global Competitiveness Report 2018", World Economic Forum. available at: http://www3.weforum.org/docs/GCR2018/05FullReport/TheGlobalCompetitiveness Report2018.pdf.

5. Hiski T. "We are preparing for the digital transformation in five steps", ["Gotovimsja k cifrovoj transformacii $\mathrm{v}$ pjat' shagov"], CAD / CAM and manufacturing processes: publications. available at: https://www.dreambird.ru/articles/2018/5-steps-digitaltransformation.

6. Steliah S. "Six barriers to digital transformation and strategies to overcome them", ["Shest' bar'erov na puty cyfrovoj transformacyy y strategyy po yh preodolenyju"], IT-Week No. 4 (940), available at: https://www.itweek.ru/digitalization/article/detail.php?ID=201706.

7. Pushkar O.I. Grabovsky E.M., Ponomarenko E.V., (2005), "Strategic Management of the Development of E-Business and Information Resources of the Enterprise (Models, Strategies, Mechanisms): Scientific Edition", ["Strategichne upravlinnja rozvytkom elektronnogo biznesu ta informacijnyh resursiv pidpryjemstva (modeli, strategii', mehanizmy): naukove vydannja"], M., KhNEU, 478 p.

8. Shershnev Z.E. (2017), "Development of the Management System of Business Organizations in the Innovative Economy", ["Rozbudova systemy upravlinnja biznes organizacij v innovacijnij ekonomici"], monograph, L.O. Ligonenko, O.I. Garafonova, T.V. Omelyanenko and all, K., KNEU, 436 p.

9. Thompson Jr. Arthur A., Strickland III A. J. (2006), "Strategic Management. Concepts and situations for analysis", ["Strategycheskyj menedzhment. Koncepcyy y sytuacyy dlja analyza"], 12th ed., trans. from English, M., publ. Williams House, 928 p. 